\title{
The socio-economic benefits of establishing National Geoparks in China
}

\author{
1 Chinese Academy of Geological Sciences, 26 Baiwanzhuang Road, 100037 Beijing, CHINA. E-mail: zhaoxun@cags.net.cn \\ 2 Institute of Mineral Resources, Chinese Academy of Geological Sciences, 26 Baiwanzhuang Road, Beijing, CHINA
}

\begin{abstract}
Since 2000, based on a wealth of geological heritage sites and experience with their conservation, China has formally approved the establishment of forty four National Geoparks, whose distribution and characteristics are dominated by structural setting and neotectonism. Conserving and developing the sites have brought about favorable social, economic and environmental benefits, and created a positive climate for their inclusion in the world Geopark network under the patronage of UNESCO.
\end{abstract}

Geological sites record the important physical phenomena from which we can trace the evolutionary history of the Earth. They serve as an avenue for the understanding of the Earth's 4,600 Ma-history, and are the only source providing essential information on the Earth's evolutionary changes and processes. In this connection, people regard geological sites as an invaluable legacy bestowed by Mother Earth and name them a 'geological heritage'. Safeguarding and treasuring this heritage, which, once lost can never be recovered, has become a matter of common concern for the people of the global village.

The history of the study and conservation of geological remains can be traced back to ancient times. But because of underdevelopment of science and technology, no scientific answers were available then to the mysteries hidden within these phenomena, and the conservation efforts were spontaneous. Scientific research on geological remains and the progressive recognition of their significance are in a real sense the outcome of the Industrial Revolution and the development of modern science. From ignorance to science, and from spontaneity to consciousness, there is an endless progression.

\section{The establishment of Geoparks in China}

From geosites conservation to the setting up of Geoparks, China has kept close collaboration with UNESCO's Division of Earth Sciences and the International Union of Geological Sciences (IUGS), making contributions to the worldwide promotion of Geoparks and standing in the forefront worldwide.

In June 2002, the IUGS invited China, as a sponsor country, to propose to the UN an International Year of Planet Earth. In his letter to the Chinese National Committee, Dr. de Mulder stated: "This conclusion is based, among other items, on the presentation given by the Minister of Land and Resources in Rio de Janeiro, also by Song Ruixiang, and the new initiative on Geoparks, and on the continuous support of your country to the IUGS Journal Episodes. To my opinion the current position of China in the Geosciences on a world-wide scale, fully merit such a leading role."

More and more importance has been attached to the conservation of geosites and the establishment of Geoparks following the recent International Geological Congresses. The 30th IGC held in Beijing, China organized a special symposium, titled, 'Geological Sites for the World Heritage List', which promoted the establishment of Geoparks in European countries. During the 31st IGC in Rio de Janeiro, Brazil there was a symposium on Geosites, which raised the awareness of many countries. After the 31st IGC, China, Germany, Switzerland and Austria set about the construction of national geoparks, gradually forming a global network. During the 32nd IGC, to be convened in Florence, Italy in August 2004, two Topical Symposia (T16 and T17) will be related to cultural heritage and to geosites, geoparks, and geotourism, respectively; and the theme of the Special Symposium S03 will be 'Cultural heritage: International approaches and perspectives'.

To enhance the protection of world geological heritage, propel geoscientific popularization, increase the public appreciation of scientific knowledge, seek new growth points for economic development, and create employment opportunities for local residents, UNESCO took the initiative to 'promote a global network of geosites having special geological features' at its General Conference in 1997. At the 156th session of UNESCO's Executive Board in 1999, it was further clarified that a UNESCO Geopark 'comprises a number of geological heritage sites of special scientific importance, rarity or beauty; it may not be solely of geological significance but also of archaeological, ecological, historical or cultural value.' Pursuant to a decision by its Executive Board in June 2001 (161EX/Dicisions 3.3.1), UNESCO was invited to support ad hoc initiatives of member states to promote territories or natural parks having special features (so-called geoparks).

Early in 1985, Chinese geologists proposed to establish geoparks in geologically significant territories with beautiful geological landscapes, in order to enhance their conservation and gear up geoscientific surveys. In July 1987, the former Ministry of Geology and Mineral Resources (MGMR) issued the "Circular on Establishing Geological Natural Reserves (proposed)"; and for the first time the conservation of geosites was proposed in the form of ministerial regulations. In May 1995, the MGMR promulgated the "Regulations for the Protection and Management of Geosites", in which the establishment of geoparks is regarded as a tool for protecting such sites. In December 1999, the establishment of geoparks was further promoted at the National Geology-Geomorphology Protection Conference held by the Ministry of Land and Resources (MLR) in Weihai, Shandong. On April 3, 2000, the ministry approved a report made by the Department of the Geological Environment on the launching of geoparks. In August the same year, the "Circular on the Leading Organization and Staffing of National Geosites (Geoparks)" was issued; at the same time, the Review Committee of National Geosites (Geoparks) was formed. In September 2000, the MLR issued the "Circular on the Nomination of National Geoparks", with the "National Geopark Nomination Form", "Outlines of a Report on the Integrated Investigation of National Geoparks", "Guidelines for the Overall Planning of National Geoparks (proposed)", "Organization and Working Regulations of the Review Committee of National Geosites (Geoparks)", and "Review Standards for National Geoparks" attached. These have brought the establishment and management of China's National Geoparks into the orbit of legislation and healthy development.

Since 2000, provinces, autonomous regions and municipalities of China have recommended quite a number of geological heritage sites, and applied for their designation as National Geoparks. Through strict review and appraisal, forty four National Geoparks have been approved in two batches so far (Table 1). 
Table 1 Classification and features of major geoheritage sites of National Geoparks of China.

\begin{tabular}{|c|c|c|c|c|c|}
\hline Category & $\begin{array}{c}\text { Representative } \\
\text { National Geopark }\end{array}$ & Major features of geoheritage & $\begin{array}{l}\text { Controlling geological } \\
\text { setting }\end{array}$ & $\begin{array}{l}\text { Relevant natural } \\
\text { conditions }\end{array}$ & $\begin{array}{l}\text { Representative } \\
\text { major humanistic } \\
\text { characteristics }\end{array}$ \\
\hline \multirow[t]{5}{*}{$\begin{array}{l}\text { Stratigraphic } \\
\text { heritage }\end{array}$} & 9. Fuping in Hebei & $\begin{array}{l}\text { Type section of Achaean } \\
\text { Longquanguan Formation. }\end{array}$ & $\begin{array}{l}\text { Pediment fault system of } \\
\text { Taihang Mountains, } \\
\text { fault-block mountain } \\
\text { masses. }\end{array}$ & $\begin{array}{l}\text { Waterfalls, hot } \\
\text { springs. }\end{array}$ & $\begin{array}{l}\text { Early-stage activities } \\
\text { of Chinese geologists. }\end{array}$ \\
\hline & 18. Songshan in Henan & $\begin{array}{l}\text { Three distinct unconformity } \\
\text { interfaces from the } 3.5 \text { Ga- } \\
\text { Achaean Era to the Proterozoic / } \\
\text { Mid-Proterozoic and Paleozoic / } \\
\text { Upper Paleozoic; naming place } \\
\text { of three major tectonic } \\
\text { movements. }\end{array}$ & $\begin{array}{l}\text { Differential elevation } \\
\text { generated by block } \\
\text { movement on the North } \\
\text { China Platform. }\end{array}$ & $\begin{array}{l}\text { Precipices, perilous } \\
\text { peaks, dense forests. }\end{array}$ & $\begin{array}{l}\text { Shaolin Temple; } \\
\text { Songyang Academy } \\
\text { of Classical Learning; } \\
\text { tower forest. }\end{array}$ \\
\hline & 5. Jixian in Tianjin & $\begin{array}{l}\text { Mid-Upper Proterozoic } \\
\text { stratigraphic section }(1.8-0.8 \mathrm{Ga}), \\
\text { rich fossils, macroscopic algae } \\
\text { earlier than } 1.7 \mathrm{Ga} \text {. }\end{array}$ & $\begin{array}{l}\text { Gently occurring old } \\
\text { stratigraphic section on } \\
\text { the North China Platform. }\end{array}$ & $\begin{array}{l}\text { Carbonate peak } \\
\text { cluster landform. }\end{array}$ & $\begin{array}{l}\text { Huangya Pass, } \\
\text { important ancient } \\
\text { battlefields. }\end{array}$ \\
\hline & $\begin{array}{l}\text { 24. Changshan in } \\
\text { Zhejiang }\end{array}$ & $\begin{array}{l}\text { Ordovician Darriwilian GSSP; } \\
\text { reef limestone; karst. }\end{array}$ & $\begin{array}{l}\text { Stable carbonate neritic } \\
\text { deposits on the Yangtze } \\
\text { Platform. }\end{array}$ & Karst hills. & $\begin{array}{l}\text { Close to the Taihu } \\
\text { Lake scenic spots. }\end{array}$ \\
\hline & $\begin{array}{l}\text { 13. Luochuan in } \\
\text { Shaanxi }\end{array}$ & $\begin{array}{l}\text { Type section of loess deposits in } \\
\text { China; loess landforms. }\end{array}$ & $\begin{array}{l}\text { Loess deposition area in } \\
\text { western North China } \\
\text { Platform. }\end{array}$ & $\begin{array}{l}\text { Loess gullies, } \\
\text { plateaus, hills and } \\
\text { ridges; sparse } \\
\text { dry-land vegetation. }\end{array}$ & $\begin{array}{l}\text { Loess fork customs } \\
\text { and culture; venue of } \\
\text { Luochuan Conference } \\
\text { in the history of the } \\
\text { Chinese Communist } \\
\text { Party. }\end{array}$ \\
\hline \multirow[t]{7}{*}{$\begin{array}{l}\text { Paleontological } \\
\text { heritage }\end{array}$} & $\begin{array}{l}\text { 42. Chengjiang in } \\
\text { Yunnan }\end{array}$ & $\begin{array}{l}\text { Early Cambrian }(0.53 \mathrm{Ga}) \\
\text { explosive biomultiplication, } \\
\text { synchronous emergence of tens } \\
\text { of biologic groups and species. }\end{array}$ & Stable neritic environment. & $\begin{array}{l}\text { Hills, lakes (rift } \\
\text { lakes). }\end{array}$ & $\begin{array}{l}\text { Fuxianhu lake } \\
\text { sceneries. }\end{array}$ \\
\hline & 36. Anxian in Sichuan & $\begin{array}{l}\text { Bioherms produced by stretches } \\
\text { of siliceous sponge; karst } \\
\text { landforms. }\end{array}$ & $\begin{array}{l}\text { Western edge of Yangtze } \\
\text { Platform. }\end{array}$ & $\begin{array}{l}\text { Longmenshan } \\
\text { moderate- to-low } \\
\text { hills; forests. }\end{array}$ & $\begin{array}{l}\text { Ancient temples, } \\
\text { fortified villages, } \\
\text { strongholds. }\end{array}$ \\
\hline & 38. Zigong in Sichuan & $\begin{array}{l}\text { Burial place of many kinds of } \\
\text { dinosaur fossils; complete fossil } \\
\text { skeletons; dinosaur dung. }\end{array}$ & $\begin{array}{l}\text { Yangtze Platform; } \\
\text { Mesozoic inland lakes. }\end{array}$ & $\begin{array}{l}\text { Central Sichuan red } \\
\text { bed hills. }\end{array}$ & $\begin{array}{l}\text { Provincial guilds; } \\
\text { ancient salt wells over } \\
1,000 \mathrm{~m} \text { in depth. }\end{array}$ \\
\hline & 15. Liujiaxia in Gansu & $\begin{array}{l}\text { Dinosaur footprints, the largest } \\
\text { being over } 1 \mathrm{~m} \text { in diameter. }\end{array}$ & $\begin{array}{l}\text { Mesozoic inland lakes in } \\
\text { western North China } \\
\text { Platform. }\end{array}$ & $\begin{array}{l}\text { Valleys in the upper } \\
\text { reaches of the Yellow } \\
\text { River. }\end{array}$ & $\begin{array}{l}\text { Liujiaxia power station } \\
\text { and reservoir. }\end{array}$ \\
\hline & 6. Yanqing in Beijing & $\begin{array}{l}\text { Silicified wood buried in situ in } \\
\text { groups. }\end{array}$ & $\begin{array}{l}\text { Northern edge of North } \\
\text { China Platform; Mesozoic } \\
\text { inland basin brought about } \\
\text { by Yanshan tectonic belt. }\end{array}$ & $\begin{array}{l}\text { Moderate-to-low } \\
\text { mountains. }\end{array}$ & $\begin{array}{l}\text { A large amount of } \\
\text { humanistic relics; } \\
\text { ancient rock } \\
\text { dwellings. }\end{array}$ \\
\hline & 1. Jiayin in Heilongjiang & $\begin{array}{l}\text { Dinosaur fossils; the first } \\
\text { dinosaur fossil unearthed in } \\
\text { China, being also the one of } \\
\text { terminal Cretaceous in China; } \\
\text { angiosperm fossils. }\end{array}$ & Wandashan massif. & $\begin{array}{l}\text { Natural landscape of } \\
\text { northernmost China. }\end{array}$ & $\begin{array}{l}\text { Sanjiang recreational } \\
\text { area in Northeast } \\
\text { China. }\end{array}$ \\
\hline & $\begin{array}{l}\text { 10. Shanwang in } \\
\text { Shandong }\end{array}$ & $\begin{array}{l}\text { Rich and well preserved } \\
\text { Mesozoic fossils of ten-odd kinds } \\
\text { and } 600 \text {-odd species of fish, } \\
\text { reptiles, amphibian, mammal, } \\
\text { and insects, plants. }\end{array}$ & Volcanic fault basins. & $\begin{array}{l}\text { Volcanic cones, } \\
\text { craters, crater lakes. }\end{array}$ & Museums. \\
\hline \multirow[t]{2}{*}{$\begin{array}{l}\text { Structural } \\
\text { geological heritage }\end{array}$} & $\begin{array}{l}\text { 19. Baotianman in } \\
\text { Henan }\end{array}$ & $\begin{array}{l}\text { Traces of tectonic and } \\
\text { metamorphic processes. }\end{array}$ & $\begin{array}{l}\text { Central (Qinling) orogenic } \\
\text { belt of continental China. }\end{array}$ & $\begin{array}{l}\text { Biodiversity at the } \\
\text { juncture of the north } \\
\text { and south climatic } \\
\text { zones in China; thick } \\
\text { vegetation. }\end{array}$ & Nature reserves. \\
\hline & $\begin{array}{l}\text { 37. Longmenshan in } \\
\text { Sichuan }\end{array}$ & $\begin{array}{l}\text { Long-range nappe structures } \\
\text { (Longmenshan tectonic belt). }\end{array}$ & $\begin{array}{l}\text { Juncture of Qinghai-Tibet } \\
\text { Plateau and the western } \\
\text { margin of Yangtze } \\
\text { Platform. }\end{array}$ & Zhongshan forest. & $\begin{array}{l}\text { Ancient temples, } \\
\text { fortified villages, } \\
\text { strongholds, caves. }\end{array}$ \\
\hline
\end{tabular}


(continued)

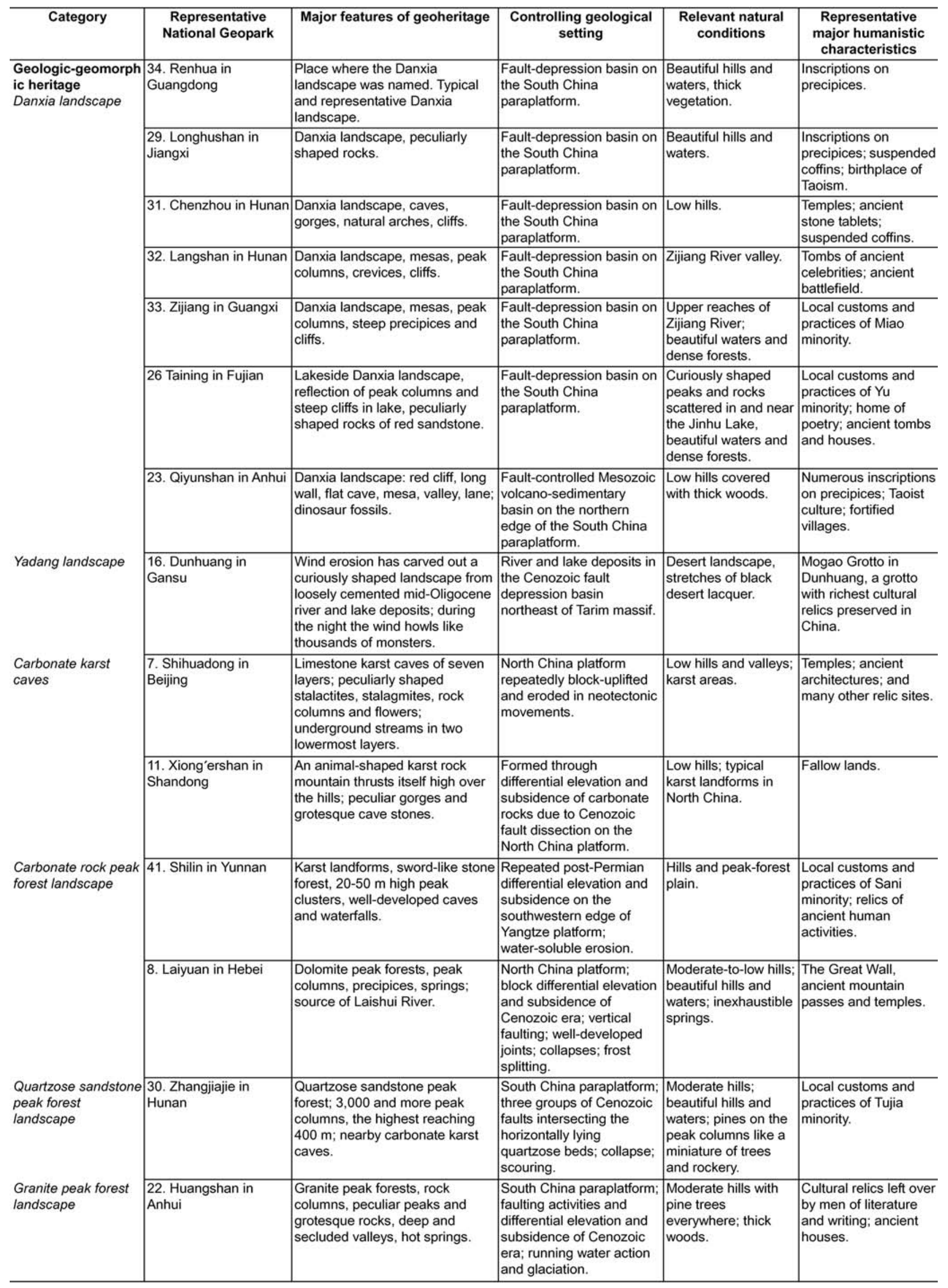


(continued)

\begin{tabular}{|c|c|c|c|c|c|}
\hline Category & $\begin{array}{c}\text { Representative } \\
\text { National Geopark }\end{array}$ & Major features of geoheritage & $\begin{array}{l}\text { Controlling geological } \\
\text { setting }\end{array}$ & $\begin{array}{l}\text { Relevant natural } \\
\text { conditions }\end{array}$ & $\begin{array}{l}\text { Representative } \\
\text { major humanistic } \\
\text { characteristics }\end{array}$ \\
\hline & $\begin{array}{l}\text { 3. Hexigten in Inner } \\
\text { Mongolia }\end{array}$ & $\begin{array}{l}\text { Columnar peaks resembling } \\
\text { human beings, animals or } \\
\text { castles, produced by granites } \\
\text { with well-developed horizontal } \\
\text { joints as a result of frost splitting, } \\
\text { freeze-and-thaw action and wind } \\
\text { erosion. }\end{array}$ & $\begin{array}{l}\text { Juncture of Xingmeng } \\
\text { geosyncline fault belt and } \\
\text { Yanshan tectono- } \\
\text { magmatic belt on the } \\
\text { northern edge of the } \\
\text { North China platform. }\end{array}$ & $\begin{array}{l}\text { Juncture of Da } \\
\text { Hinggan Ling } \\
\text { primeval forest, } \\
\text { Hunshandake } \\
\text { Desert, and Horqin } \\
\text { Desert. }\end{array}$ & $\begin{array}{l}\text { Cultural relics of the } \\
\text { Liao and Jin } \\
\text { dynasties; rock wall } \\
\text { paintings. }\end{array}$ \\
\hline $\begin{array}{l}\text { Glacial geologic } \\
\text { heritage } \\
\text { Fossil glacier }\end{array}$ & 28. Lushan in Jiangxi & $\begin{array}{l}\text { Birthplace of Quaternary } \\
\text { glaciological research in China; } \\
\text { complete sections; glacial } \\
\text { remnants and their naming } \\
\text { places; old stratigraphic sections } \\
\text { of southern China; fault-block } \\
\text { mountains. }\end{array}$ & $\begin{array}{l}\text { Old continental nucleus of } \\
\text { the South China } \\
\text { paraplatform; differential } \\
\text { elevation and subsidence } \\
\text { in the fault-block } \\
\text { movement of Cenozoic. }\end{array}$ & $\begin{array}{l}\text { The Lushan } \\
\text { Mountain, the } \\
\text { Boyang Lake, and } \\
\text { the Yangtze River } \\
\text { enhancing each } \\
\text { other's beauty; thick } \\
\text { woods. }\end{array}$ & $\begin{array}{l}\text { Ancient academy of } \\
\text { classical learning; } \\
\text { inscriptions on } \\
\text { precipices; temples; } \\
\text { buildings of various } \\
\text { styles of the world. }\end{array}$ \\
\hline Modern glacier & $\begin{array}{l}\text { 39. Hailuogou in } \\
\text { Sichuan }\end{array}$ & $\begin{array}{l}\text { A 29-km long modern glacier on } \\
\text { the east of the Gongga } \\
\text { Mountains, the lowermost ice } \\
\text { tongue going down to } 2,750 \mathrm{~m} \\
\text { a.s.l.; hot springs }\end{array}$ & $\begin{array}{l}\text { Juncture of the western } \\
\text { edge of the Yangtze } \\
\text { platform and the folded } \\
\text { belt of the Kangdian } \\
\text { Hengduan Mountains, } \\
\text { strongly uplifted in } \\
\text { Cenozoic. }\end{array}$ & $\begin{array}{l}\text { Coexistence of vast } \\
\text { primeval forest, } \\
\text { glacier and spring. }\end{array}$ & $\begin{array}{l}\text { Culture of the Zang } \\
\text { minority; Moxi ancient } \\
\text { town. }\end{array}$ \\
\hline \multirow[t]{6}{*}{$\begin{array}{l}\text { Volcanological } \\
\text { heritage }\end{array}$} & $\begin{array}{l}\text { 2. Wudalianchi in } \\
\text { Heilongjiang }\end{array}$ & $\begin{array}{l}\text { Volcanic landforms; } 14 \\
\text { volcanoes, erupted from Tertiary } \\
\text { to Quaternary with the latest } \\
\text { eruption in } 1721 ; \text { typical } \\
\text { morphological features of edifice, } \\
\text { volcanic lake and lava. }\end{array}$ & $\begin{array}{l}\text { Effects of Circum-Pacific } \\
\text { tectonic activities; East } \\
\text { Asian rift series. }\end{array}$ & $\begin{array}{l}\text { Plains, hills, } \\
\text { well-developed } \\
\text { vegetation. }\end{array}$ & $\begin{array}{l}\text { Ancient temple; ore } \\
\text { sludge; medicine } \\
\text { spring. }\end{array}$ \\
\hline & $\begin{array}{l}\text { 27. Zhangzhou in } \\
\text { Fujian }\end{array}$ & $\begin{array}{l}\text { Littoral volcanic rocks; basaltic } \\
\text { prismatic joints; volcanic vents } \\
\text { and cones; marine erosion } \\
\text { landform. }\end{array}$ & $\begin{array}{l}\text { Effects of Circum-Pacific } \\
\text { tectonic activities; East } \\
\text { Asian rift series. }\end{array}$ & $\begin{array}{l}\text { Coastal hills, sand } \\
\text { beaches, islands. }\end{array}$ & $\begin{array}{l}\text { Ancient battery; } \\
\text { castle; temple; } \\
\text { recreational sites. }\end{array}$ \\
\hline & $\begin{array}{l}\text { 43. Tengchong in } \\
\text { Yunnan }\end{array}$ & $\begin{array}{l}\text { Modern volcanic landform; } \\
\text { geothermal springs; biodiversity; } \\
\text { various hot springs; sinter. }\end{array}$ & $\begin{array}{l}\text { Folded belt of Kangdian } \\
\text { Hengduan Mountains; } \\
\text { intense neotectonism. }\end{array}$ & $\begin{array}{l}\text { Low hills; spring } \\
\text { lakes; thick } \\
\text { vegetation. }\end{array}$ & $\begin{array}{l}\text { Ancient border city; } \\
\text { customs and practices } \\
\text { of ethnic minorities. }\end{array}$ \\
\hline & $\begin{array}{l}\text { 35. Huguangyan in } \\
\text { Guangdong }\end{array}$ & Volcanic landscape; Ma'er Lake. & $\begin{array}{l}\text { Circum-Pacific volcanic } \\
\text { rocks. }\end{array}$ & $\begin{array}{l}\text { Hills; thick } \\
\text { vegetation; lakes. }\end{array}$ & $\begin{array}{l}\text { Temples; inscriptions } \\
\text { on precipices. }\end{array}$ \\
\hline & 21. Fushan in Anhui & $\begin{array}{l}\text { Caves created by weathering of } \\
\text { volcanic rocks; complete volcanic } \\
\text { mechanism; volcanic cone; } \\
\text { crater; cinder; lava flow. }\end{array}$ & $\begin{array}{l}\text { Fault depression basin of } \\
\text { East Asian rift valley } \\
\text { series. }\end{array}$ & Hills; thick woods. & $\begin{array}{l}\text { Temples; inscriptions } \\
\text { on precipices. }\end{array}$ \\
\hline & 25. Linghai in Zhejiang & $\begin{array}{l}\text { Late Cretaceous volcanic rocks; } \\
\text { volcanic landform; columnar } \\
\text { joints; pterosaur and bird fossils. }\end{array}$ & $\begin{array}{l}\text { Circum-Pacific } \\
\text { tectono-volcanic rock belt. }\end{array}$ & Coastal hills. & Ancient architecture. \\
\hline \multirow[t]{2}{*}{$\begin{array}{l}\text { Hydrological } \\
\text { heritage }\end{array}$} & $\begin{array}{l}\text { 12. Hukou waterfalls on } \\
\text { the Yellow River }\end{array}$ & $\begin{array}{l}\text { The greatest waterfall on the } \\
\text { mainstream of the Yellow River; } \\
\text { narrow and deep gorges; } \\
\text { retrogressive erosion. }\end{array}$ & $\begin{array}{l}\text { North China platform; a } \\
\text { series of joints formed by } \\
\text { the influence of the } \\
\text { Indo-Sinian movement, } \\
\text { which controlled the } \\
\text { erosion of the river. }\end{array}$ & $\begin{array}{l}\text { Yellow River valley; } \\
\text { incision. }\end{array}$ & $\begin{array}{l}\text { Inscriptions of ancient } \\
\text { poems; relic sites of } \\
\text { World War II. }\end{array}$ \\
\hline & $\begin{array}{l}\text { 17. Yuntaishan in } \\
\text { Henan }\end{array}$ & $\begin{array}{l}\text { Piedmont fault of the Taihang } \\
\text { Mountains has created long } \\
\text { walls, red cliffs, narrow gorges, } \\
\text { lane-like valleys, urn-like valleys; } \\
\text { many waterfalls, of which the } \\
\text { Tianpo waterfall being } 304 \mathrm{~m} \text { in } \\
\text { height. }\end{array}$ & $\begin{array}{l}\text { North China platform; } \\
\text { differential elevation and } \\
\text { subsidence of the } \\
\text { piedmont fault of the } \\
\text { Taihang Mountains. }\end{array}$ & $\begin{array}{l}\text { Moderate Mountains; } \\
\text { gorge landform; } \\
\text { dense forest. }\end{array}$ & $\begin{array}{l}\text { Temples and towers; } \\
\text { ancient trees; place } \\
\text { where the seven } \\
\text { ancient Zhulin } \\
\text { scholars lived in } \\
\text { seclusion. }\end{array}$ \\
\hline $\begin{array}{l}\text { Engineering } \\
\text { geological heritage }\end{array}$ & $\begin{array}{l}\text { 40. Daduhe valleys in } \\
\text { Sichuan }\end{array}$ & $\begin{array}{l}\text { Dadu River valley and narrow } \\
\text { gorges and lane-like valleys of its } \\
\text { tributaries; Dawa Mountain and } \\
\text { Quaternary glacier; formidable } \\
\text { huge project of Cheng-Kun } \\
\text { Railway cutting through the } \\
\text { valleys with bridges linking to } \\
\text { culverts and caves to tunnels. }\end{array}$ & $\begin{array}{l}\text { Western edge of Yangtze } \\
\text { platform; N-S trending } \\
\text { Chuandian structural belt; } \\
\text { intense effects of } \\
\text { neotectonism. }\end{array}$ & $\begin{array}{l}\text { Moderate and low } \\
\text { mountains; deep } \\
\text { valleys and dense } \\
\text { forest. }\end{array}$ & $\begin{array}{l}\text { Customs and } \\
\text { practices of Zang and } \\
\text { Yi minorities; } \\
\text { Cheng-Kun Railway } \\
\text { project. }\end{array}$ \\
\hline \multirow{2}{*}{$\begin{array}{l}\text { Geohazard heritage } \\
\text { Large-scale } \\
\text { mountain mass slide } \\
\text { induced by collapse } \\
\text { earthquake }\end{array}$} & $\begin{array}{l}\text { 14. Cuihuashan in } \\
\text { Shaanxi }\end{array}$ & $\begin{array}{l}\text { Earthquake-induced mountain } \\
\text { collapse and accumulation, which } \\
\text { dammed the river valley to create } \\
\text { a lake. }\end{array}$ & $\begin{array}{l}\text { Piedmont faulting on the } \\
\text { north of Qinling } \\
\text { Mountains. }\end{array}$ & $\begin{array}{l}\text { Moderate mountains; } \\
\text { talus of boulder } \\
\text { gravel. }\end{array}$ & $\begin{array}{l}\text { Inscriptions on } \\
\text { precipices by ancient } \\
\text { celebrities. }\end{array}$ \\
\hline & 44. Yigong in Tibet & $\begin{array}{l}\text { Modern glacier; high mountain } \\
\text { and deep valley; large-scale } \\
\text { mountain mass slide; vertical } \\
\text { zoning of vegetation. }\end{array}$ & $\begin{array}{l}\text { Uplifted belt of } \\
\text { Qinghai-Tibet Plateau. }\end{array}$ & $\begin{array}{l}\text { High mountain; deep } \\
\text { valley; modern } \\
\text { glacier. }\end{array}$ & \\
\hline
\end{tabular}




\section{The socio-economic benefits of establishing Geoparks in China}

It has been centuries since our ancestors realized and enjoyed geotourism resources. In their masterpieces through the ages, many poets and writers have sung the praises of renowned mountains and great rivers, and their audiences can feel poetry in the painting and painting in the poetry. Some monks and travelers, being free from worldly cares, abandoned themselves to the mountains and rivers, spurred by the theory that man is an integral part of Nature. The 5,000-year long Chinese history is also the history of natural resources exploration and protection. The recognition, exploration and protection of geotourism resources are integrated smoothly in the nation's development. They have provided a broad material basis for the advance of the national culture, and the latter in turn has added value to the cultural connotation of the resources. The perfect harmony of the rich and colorful geotourism resources with the long history and civilization of China is the major characteristic of Chinese National Geoparks, and also an important factor for China to take the lead in promoting the UNESCO-sponsored Geopark Programme at the state level.

The 44 national Geoparks are located in territories with relatively focused geological heritage sites. The approval of National Geoparks has stimulated provincial and municipal governments to attach greater importance to the protection of China's geological heritage. Many local governments have reviewed and approved local geoparks at the relevant levels. As a result, a network of geological heritage protection, with National Geoparks as the core, has begun to emerge in China. Geoparks have become a new growth point of local economies, and created a new field of employment. In return, geological popularization is well implemented; geoenvironmental protection has begun to win support among local people; active academic exchanges in this aspect have led to the establishment of many thematic research centers; and the scientific-technological connotation of tourism has increased.

\section{Strengthening ties and coopera-tion with foreign geoscientists}

Exchanges and co-operation between Chinese and foreign geologists have been centered mainly on scientific research, with a few on putting geoscience to the service of the social economy. However, in geoheritage protection we have developed a new field of cooperation.

China is among the countries that have actively joined the promotion of the UNESCO-sponsored 'Geopark Programme'. Prof. Zhao Xun, first author of this paper, took part in the feasibility study of the Programme organized by UNESCO. At the 2002 IGCP EC meeting in Paris, China's presentation based on its 44 National Geoparks already approved was warmly welcomed. It was generally acknowledged at the meeting that China had given a great impetus to the Programme. Even those who had dissented from the Programme commended China as saying, 'In developing countries, setting up Geoparks is a feasible way to protect the geoheritage.'

In the new field of the promotion of National Geoparks, geoscientists at home and abroad collaborate closely, aiming at a common goal of global sustainable development.

\section{Increasing scientific content in the tourism industry}

UNESCO has requested that geoparks should serve as a base for scientific popularization. In this connection, we have launched an allround improvement in tourism information, the erection of sign posts, tourism route design, guide book compilation and tour guide training, as well as in the furnishing of museums. Knowledge of earth sciences, meteorology, zoology and botany has been injected in information to replace fairy tales and folklore. Scientific popularization has been integrated with tourism, and education with recreation. So far, 33 of the 44 National Geoparks have completed the improvement. Today
Geoparks widespread in the country have become bases of scientific popularization for the general public.

\section{Geoheritage and geoenvironmen-tal protection becoming common knowledge}

Geosites are records of geological history handed down for tens and thousands of millions of years, whereas the history of mankind is merely millions of years and mankind's recorded history is only thousands of years. To understand the present status of the planet Earth on which we are living, the study of the phenomena and records that have preserved through different geological processes is indispensable. Only in this way can we predict the evolutionary trend of the Earth work out pertinent measures and take precautions in order to achieve a harmonized co-existence between heaven, earth and man, and to bring about sustainable development. The establishment of geoparks has helped local governments and inhabitants become aware of the importance of safeguarding geoheritage resources and the geoenvironment, and conscientiously take part in the campaign. As a result, a new social mode of cherishing the geoheritage and geological environment is being cultivated. For instance, people living in the area of the Yuntaishan National Geopark, Henan Province, are taking great care of the woods and no one is allowed to fell trees there. Following their example, protecting natural resources and the geological environment has become a common practice among residents of the surrounding areas.

\section{Enhancing the local economy and employment}

By virtue of geosites and favorable geoenvironment, local governments have regarded geotourism as a new economic growth point which can alleviate the expense of geoheritage preservation, increase local revenues and enhance employment. Take again as an example the Yuntai National Geopark in Henan. This Geopark, approved in 2001, covers an area of $190 \mathrm{sq} \mathrm{km}$ and is characterized by a combination of 'cliff-valley-forest-waterfall'. With the addition of scientific and cultural content to tourism, it has become a provincial base for science promotion and education, and attracted a great many young students as well as leading scholars. In 2001, the number of visitors reached 600,000 , and the income from admission fees amounted to 14 million yuan, twice the average of the previous years. In 2002, the number of visitors soared to 940,000 , and the income from admission fees swelled to 27.2 million yuan, up $68 \%$ and $97 \%$, respectively, compared with the previous year. Tourism spurred tertiary industry and enhanced local employment. In 2002 , the revenues from tertiary industry increased to 620 million yuan, $15 \%$ over the previous year. More than 60 hotels were newly built in the county, and about 4,000 jobs were offered by tourism development. Meanwhile, the county attracted investment from domestic and foreign enterprises. The projects under construction or negotiation in this aspect totaled 379 million yuan-worth.

Another example is the Jinhu National Geopark in Taining County, Fujian Province, constructed in 2000 and characterized by 'waterside Danxia landscape'. The related tourism projects attract a great number of visitors. In 2001, the total revenues from tourism reached 202 million yuan, $35.7 \%$ over the previous year, accounting for $13.5 \%$ of the county's GDP. Revenues from tourism-related tertiary industry increased to 450 million yuan, up $12.3 \%$ compared with the previous year and accounting for nearly $30 \%$ of the county's GDP. Thus, tourism has become a pillar industry of the county. It has brought along such trades as catering, transportation and cultural recreation, furnishing employment for about 2,800 people. Particularly noteworthy is the resolution of the migration problem caused by the construction of the Jinhu Reservoir, which was a hard nut to crack for the county authorities. The establishment of the geopark and the speedy development of the geotourism industry has created jobs for a great many displaced people, who are now paid three to five times greater than before. As a consequence, the instability factor has been eliminated, and people are making a good living there. 
Local people of all walks of life as well as local authorities have clearly realized that the construction of geoparks can not only preserve the geological heritage, optimize the geological environment, promote the popularization of science, and add a scientific content to tourism, but are also beneficial to the local economy and employment. It is a concrete task for geology to serve the sustainable development of the social economy, and an undertaking that has enjoyed immense popular support.

\section{Geoscientific significance of China's National Geoparks}

Geological and geomorphologic landscapes in China feature numerous mountains and rivers. The 44 National Geoparks have rich geoscientific connotations. Some are renowned as the localities of rare fossils, and others for global boundary stratotype section and points (GSSPs), for significant aspects of tectonic evolution, for grotesque and attractive relief, for volcanic wonders, for vestiges of glaciation, for seismic grandeur, or for supergenic mysteries. All these sites are products of long-standing geological processes, reflecting the closely related geological setting.

\section{The geological setting of Chinese geoscientific landscape resources}

Physiographic features are the basic reflection of structural patterns, while the latter control the development of the former. Modern physiographic features of China embody a concentrated expression of the geological structures that experienced synthetic actions from both internal and external agencies during the long geological processes (Cheng Yuqi, 1994). Continental China was pieced together through these processes from several relatively long-stable landmasses and the important mobile belts distributed within them. Modern physiographic patterns are characterized by 'the step-like relief high in the west and low in the east, and the regular-spread mobile fault structural belts' (Ye Dingheng et al., 1998). The three tectono-geomorphic steps of China demonstrate regional differences in crustal movement and geotectonics (Environmental Geology Institute of the Ministry of Geology and Mineral Resources, 1991; Cheng Yuqi et al., 1994). According to $\mathrm{Wu}$ Zhenhan (2001), from west to east, the relief in China declines stepwise, giving rise to three tectono-geomorphic steps and four tectono-topographical terraces. The results are summarized below, from west to east (Figure 1).

The Qinghai-Tibet Plateau is the highest-level topographic terrace in China, confined by mountain ranges like the Pamirs, the Altun, the Qilian, the Hengduan and the Himalayas. The altitude is 3,000 $\mathrm{m}$ to $4,000 \mathrm{~m}$ a.s.l., reaching over $5,000 \mathrm{~m}$ in northern Tibet. The plateau is relatively flat at the top, high in the west and low in the east, forming 'the roof of the world'. This is the place where the major rivers of Asia originate. The Hengduan Mountains to the east rose quickly in Cenozoic and were incised strongly by the Jinsha, Nujiang, and Lancang Rivers, bringing forth high mountains and deep valleys with the relative altitude difference reaching over $3,000 \mathrm{~m}$. This is the first step in China's topography.

The second-level terrace encompasses northern and eastern Tibet, consisting of secondary plateaus like the Alxa, Inner Mongolia, Loess, and Yunnan-Guizhou, accompanied by basins (e.g. Hexi Corridor, Tarim and Sichuan basins) and mountains built up by neotec-

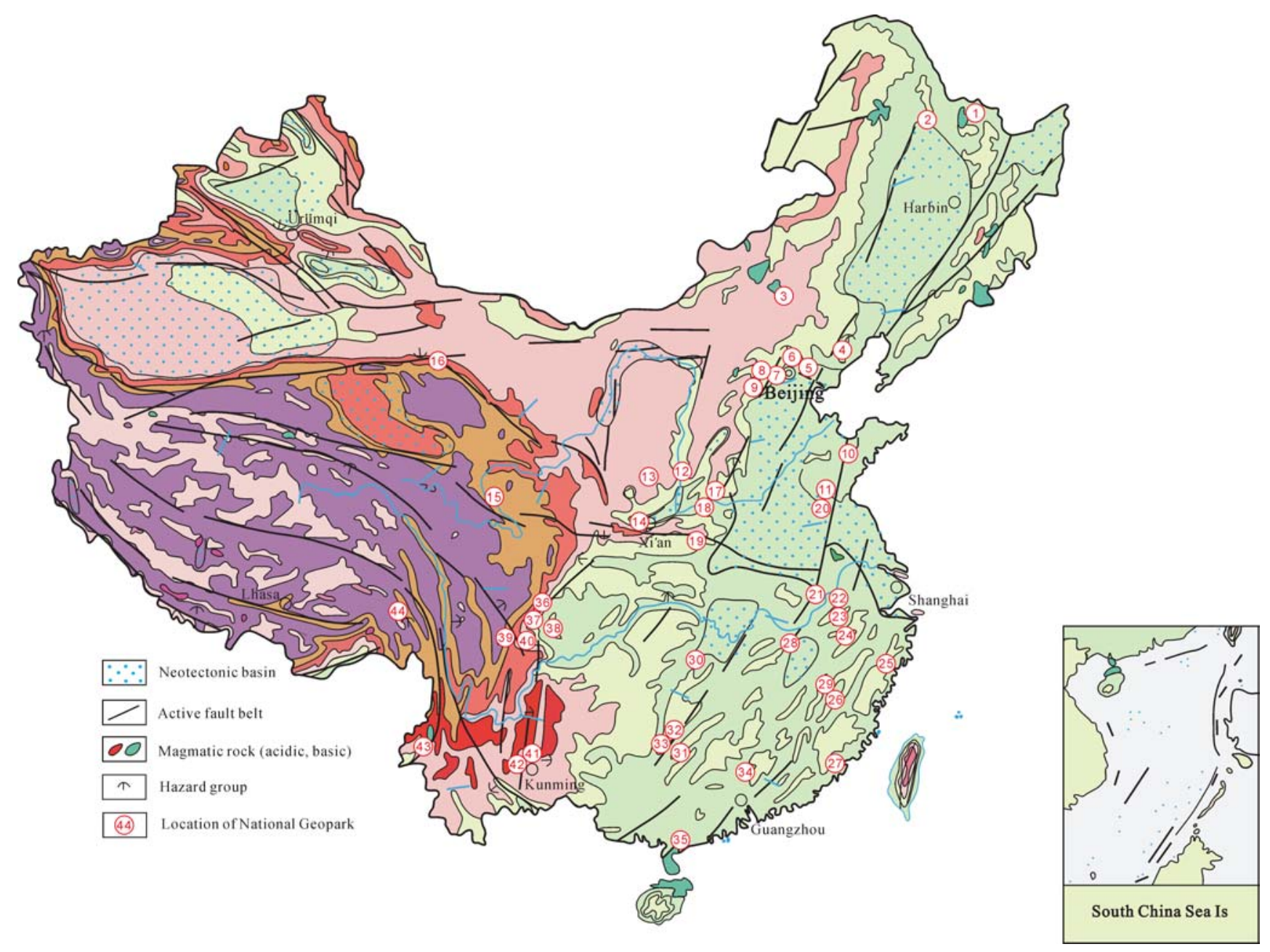

Figure 1 Sketch map of locations of National Geoparks in China. 
tonic movements (e.g. Tianshan, Qinling, and Yinshan ranges). The Da Hingganling-Taihang-Xuefeng Mountains form the eastern border, reaching 1,000 to 2,000 $\mathrm{m}$ a.s.l. This is the second step in China's topography.

On the third-level terrace, the vast hilly plain and low mountain areas in eastern China are 500-1,000 a.s.1., while the Northeast China plain, the North China plain and the plain on the middle and lower reaches of the Yangtze River are all below $200 \mathrm{~m}$ a.s.l. In the east there are volcanic rocks distributed intermittently along the coast and the middle-to-low mountains formed by uplifted blocks. These constitute the third step in China's topography.

The fourth terrace consists of the gentle continental shelves of the Yellow Sea, the East China Sea and the South China Sea, as well as the adjacent littoral plain areas, being the natural extension of continental China, with slope angle less than $1^{\circ}$. On the terrace there are deltas of the Yellow, Yangtze and Pearl rivers, a crisscrossing network of rivers and scattered paleolacustrine bogs.

The creation of the overall features of the three steps and four terraces is controlled by the Earth's unified dynamic mechanism with driving forces coming from the relative movement, compression, subduction and sliding of the Eurasian, Indian, Pacific and Philippine plates. The variation of gravity and magnetic fields and, in particular, the abrupt changes of the geophysical fields, as well as the depth migrations of Moho, are in good agreement with geothermal gradients, showing the geodynamic basis of the regularity of subsurface topographic changes. Zhu Xia et al. (1990) pointed out: 'Matching the northward movement of the Pacific plate, the compressions of continental blocks are consistent with the NNE-striking, dominantly lefthand translational movements; and the similarly striking volcanic rock belt of Late Jurassic-Early Cretaceous can be related to crustal melting occurred under strong shearing. These combined to create the network pattern composed of the inherited NNE- and NWW-striking movements started in Late Jurassic and continued in the Cretaceous up to the Tertiary.'

\section{Classification of Chinese National Geoparks and their geological setting}

The distribution and classification of Chinese National Geoparks have a close relationship to the geological setting and geomorphic features. Nowadays, with different focuses of attention of the author, the criteria of classification are different. The Operational Guidelines of the network of Geoparks under UNESCO'S patronage place particular emphasis on geoheritage-related disciplines. There are large-scale geoheritage sites of economic geology and mining relics, engineering geology, history of the Earth, geomorphology, glacial geology, hydrogeology, mineralogy, paleontology, petrography, sedimentology, soil sciences, stratigraphy, structural geology, and volcanology. Many Chinese geologists have proposed classifications of geotourism resources (Tao Kuiyuan et al., 2000; Chen Anze et al., 1991). These are virtually the same, placing stress mostly on the subjects and the major geological agents concerned.

Based on a synthetical analysis of the 44 National Geoparks already established, the geological heritage sites are classified in the following categories: stratigraphic heritage, paleontological heritage, structural-geological heritage, geologic-geomorphic heritage (subclassified to Danxia landscape, Yadang landscape, carbonate karst caves, carbonate rock peak forest landscape, quartzose sandstone peak forest landscape, granite peak forest landscape), glacial geologic heritage, volcanological heritage, hydrogeological heritage, engineering geological heritage, and geohazard heritage (earthquake-induced collapse and landslide). These categories can be further subdivided.

The controlling factors in relation to the genesis of the areas where the National Geoparks are located can be analyzed as follows:

\section{The geoparks are relatively concentrated in the three topo- graphic step areas.}

In the first step area, there is Liujiaxia in Yongjing County in Gansu Province; Longmenshan in Sichuan Province; Anxian in Sichuan Province; Daduhe Valley in Sichuan Province, Hailuogou in Sichuan Province, and Tengchong in Yunnan Province.

In the second step area, there is Hexigtan in Inner Mongolia, Yanqing in Beijing, Baishishan in Hebei Province's Laiyuan County in, Tianshengqiao in Hebei Province's Fuping County, Yuntaishan in Henan Province's Xiuwu County, Baotianman in Henan Province's Xixiang County, Hukou Waterfall on the Yellow River, and Zhangjiajie in Hunan Province.

In the third step area, there is Qinhuangdao in Hebei Province, Linghai in Zhejiang Province, Zhangzhou in Fujian Province and Huguangyan in Guangdong Province.

The above three topographic step areas have unique features of intense tectonic processes and varied landforms. For example, in the magnificent Circum-Pacific volcanic belt of the third step area, each sector has its own charming scenery of lofty mountains or towering crags. Having undergone strong differential elevation and subsidence of pediment faults, the grand Taihang and Wuling mountains of the second step area boast impressive red cliffs and waterfalls. In the first step area there occur the huge nappes of the Longmen Mountains, the surging waves in the Dadu Valley, and the gushing hot springs in Tengchong. Meanwhile, along these step areas differential crustal movements have unraveled quite a few of mysteries concerning the evolutionary history of the Earth's crust. For example, in Baotianman, Baishishan, Yuntaishan and Tianshengqiao many invaluable records displaying the crust's early evolution have been elevated to the surface, and are regarded as 'textbooks of geological history'; in Zhangiajie and Hexigtan, active geological structures have brought great changes to the landscape, displaying the extremely skillful craftsmanship of Nature.

\section{The geoparks on the four terraces are partly affected by local faulting.}

For instance, the wonderful stone forest in Yunnan, the secluded Lushan Mountains in Jiangxi, the beautiful Huangshan Mountains in Anhui and the precipitous Songshan Mountains in Henan were all created by faulting and differential elevation and subsidence occurring in Mesozoic and Cenozoic times. Intersecting joints provide favorable conditions for river or glacier erosion, giving rise to the mystical stone forest, the towering peaks, the fin-shaped ridges and the deep gullies that offer a wide range of attractions on the vast expanse of the terrace.

In the Yangtze paraplatform of southern China, affected by the activities of the Pacific plate, the NE-NNE-striking faulting has brought about a series of volcanic intracontinental basins since the Mesozoic, which, under dry climatic conditions, created gigantic red sandy conglomerates cemented by calcareous and muddy materials. The red layers, uplifted by subsequent faulting under the influence of the long-range effects of the Himalayan orogenesis of the Cenozoic era, have undergone water erosion and produced many peculiar geomorphic features like mesas, peak forests, peak columns, long precipices, narrow gorges, urn-shaped valley, tunnel-like gorges, rock corridors, flat beds along cliff faces, etc.

As part of the Circum-Pacific belt, the peri-Pacific region in the stable platform area of eastern China has experienced the impacts of four episodes of volcanic activity since the Cenozoic (locally late Mesozoic), bringing forth the 'East Asia continental rift belt' (Liu Jiaqi, 1999). The activity of the fault system led to the upsurge and eruption of magma. 'The orientation of the tectonic line and the volcanic belt are in good agreement with the continental margin. Volcanic activities develop progressively towards the margin.' (Liu Jiaqi, 1999) Among the National Geoparks, Wudalianchi in Heilongjiang Province, Fushan in Anhui Province, Linghai in Zhejiang Province, 
Zhangzhou in Fujian Province and Huguangyan in Guangdong Province are typical of the series of volcanoes controlled by different tectonic positions in different phases of the East Asia continental rift belt. The features of the volcanic rocks show clearly the regularity of the changes.

\section{In quite a few of the geoparks, the groups of geological heritage} sites are not products of a single geological process.

Volcanic eruptions took place four times in the area of the Zhangzhou Volcanic Geopark, forming mutually superimposed volcanic rocks with different tectonic characteristics. The magnificent and lofty columnar joints are found in a specific horizon and position, and the exposure of the fumaroles was caused by long-term marine erosion in the late stage. The rapid differential movements of horst faults in the Lushan area since Cenozoic times has brought about towering block mountains, being an essential factor of glaciation in the Oligocene. The high resistance to weathering of the metamorphic complex was fundamental to the formation of the gorges and precipices. The embryonic form of the stone forest in Yunnan was generated in the late Permian before the eruption of the Emeishan basalts, as evidenced by basalts filled in the paleo-karst caves. Rift-faulting and differential elevation and subsidence in the N-S striking Kang-Dian fracture zone of the Cenozoic era endowed the stone forest with thousands of postures and individuality.

\section{Abrupt geological events frequently played a key role in the formation of thrilling geoheritage sites.}

According to historical records, the Cuihuashan landslide was created by an intensive earthquake that occurred along the pediment fault of the Qinling Mountains in the 5th year of the reign of Emperor Chengwang of the Zhou Dynasty (c. 11th century to 256 A.D.). Gigantic fallen rocks dammed the river courses, creating lakes, or pilled up, forming caves. The Yigong Geopark in Tibet features dammed lakes and varied landslides generated by an extensive landslide in 1999. It has become a favorable base for research into the mechanism of geohazards, and their prediction and prevention. In addition, geoparks in Shanwang, in Shandong Province, Zigong, in Sichuan Province, and other places exhibit group death and burial of ancient living beings. Research findings indicate that volcanic eruptions and environmental pollution might have played an important role in this respect.

\section{Concluding remarks}

In their probe into the nature's history, man has come to gradually understand the importance of safeguarding geological heritage; and through long practice of conserving that heritage, we have found an optimal approach for this purpose, i.e., establishing geoparks and making them special landscape areas for protecting the Earth's legacy and the geological-ecological environment. Furthermore, it is important to network them at different levels to form research bases for important geoscientific issues, educational field bases for students, and scientific popularization bases for the general public. In the course of this, the revenues from geotourism, e.g. knowledge tours, science tours and environmental protection tours, can support local economies and promote local employment. These will further sensitize local governments, economic entities and inhabitants to the value of geoheritage conservation. With the creation of the Global Network of Geoparks, it can be foreseen that mankind will, as well as protecting its historical and cultural heritages, open a new page in history in the conservation of geological heritage.

\section{References}

Chen Anze et al., 1991, An introduction to tourism geology. Peking University Press, Beijing, China, 228pp.

Cheng Yuqi et al., 1994, An introduction to regional geology of China, Geological Publishing House, Beijing, China, 517pp.
Cowie, J.W. and Winbledon, W.A.P., 1994, The world heritage list and its relevance to geology. Proceedings of the Marvexn Conference 1993, pp.71-73

Department of Geological Environment, Ministry of Land and Resources, 2002, Enter the Geoparks, Part 1. Geological Publishing House, Beijing, China, 45pp.

Department of Geological Environment, Ministry of Land and Resources, 2003, Enter the Geoparks, Part 2. Geological Publishing House, Beijing, China, 100pp.

Eder, W. 1999, "Unescogeoparks" - A new initiative for protection and sustainable development of the Earth's heritages, N. J. B. Geol. Palaont. abh. 214 (1/2), pp. 353-358.

European geoparks network, European Geoparks Magazine, issue, 2002.1.

Institute of Environment and Geology under the Ministry of Geology and Mineral Resources, 1991, Tourism Geological Resources Map of China, Scale: 1:6,000,000 (with explanatory notes). Geological Publishing House, Beijing, China.

International Declaration of the rights of the memories of the Earth, 1991, Digne, France.

Ji Shu'an and Pan Jiang, 1997, The geological heritage sites and national parks in China, Engineering geology and the environment. Mannos, Koukis, Balkema, 2961-2965.

Liu Benpei et al., 2000, An introduction to Earth Sciences. Higher Education Press, Beijing, China, 368pp.

Liu Jiaqi, 1999, Volcanoes of China. Science Press, Beijing, China, 219pp.

Wu Zhenhan et al., 2001, Cenozoic tectono-morphological evolution and mechanism of continental China and its adjacent areas. Geological Publishing House, Beijing, China, 275pp.

Ye Dingheng et al., 1998, Neotectonic Map of China and its Adjacent Areas, Scale: 1:5,000,000 (with explanatory notes, 61pp.), Geological Publishing House, Beijing, China.

Zhao Xun and Wang Milly, 2002, National geoparks initiated in China, Putting geoscience in the service of society. Episodes, Vol. 25, No. 1, pp 33-37.

Zhao Xun et al., 2002, Release of the UNESCO Operational Guidelines for Geoparks and its significance. Geological Review, Vol. 48, No.5.

Zhao Ting et al., 2002, Construction of European Geoparks and its significance. Transactions of the Earth, Vol. 23, No.5, pp.454-470.

Zhu Xia et al., 1990, Mesozoic-Cenozoic sedimentary basins of China. Petroleum Industry Press, Beijing, China, 319pp.

Zhao Xun is Professor of sedimentology at Chinese Academy of Geological Sciences, Vice Secretatry General of Geological Society of China and Member of Advisory and Expert Group of Geopark supported by UNESCO. He was born in 1942 and graduated from Chengdu Institute of Geology in 1966.

Zhao Ting was graduated from Beijing United University in 1966 and recived his MSc from Institute of Information of China in 2002. He is studying for PhD in Institute of Mineral Resources, Chinese Academy of Geological Sciences.

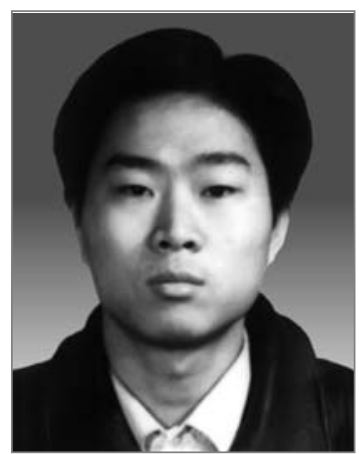

